\title{
TRPV1 Function in Mouse Colon Sensory Neurons Is Enhanced by Metabotropic 5-Hydroxytryptamine Receptor Activation
}

\author{
Takeshi Sugiura, ${ }^{1,2}$ Klaus Bielefeldt, ${ }^{3}$ and G. F. Gebhart ${ }^{1}$ \\ ${ }^{1}$ Department of Pharmacology, Carver College of Medicine, The University of Iowa, Iowa City, Iowa 52242, ${ }^{2}$ Department of Anesthesiology and Medical \\ Crisis Management, Nagoya City University Graduate School Medical Sciences, Nagoya 467-8601, Japan, and ${ }^{3}$ Division of Gastroenterology, Department of \\ Internal Medicine, University of Pittsburgh, Pittsburgh, Pennsylvania 15261
}

\begin{abstract}
Using whole-cell patch-clamp methods, we examined the hypothesis that serotonin [5-hydroxytryptamine (5-HT)] receptor activation enhances TRPV1 function in mouse colon sensory neurons in lumbosacral dorsal root ganglia, which were identified by retrograde labeling with DiI (1,1' -dioctadecyl-3,3,3',3-tetramethlindocarbocyanine methanesulfonate) injected into multiple sites in the wall of the descending colon. 5-HT increased membrane excitability at a temperature below body temperature in response to thermal ramp stimuli in colon sensory neurons from wild-type mice, but not from TRPV1 knock-out mice. 5-HT significantly enhanced capsaicin-, heat-, and proton-evoked currents with an $\mathrm{EC}_{50}$ value of $2.2 \mu \mathrm{M} .5$-HT $(1 \mu \mathrm{M})$ significantly increased capsaicin-evoked (100 nM) and proton-evoked (pH 5.5) currents 1.6-and 4.7-fold, respectively, and significantly decreased the threshold temperature for heat current activation from 42 to $38^{\circ} \mathrm{C}$. The enhancement of TRPV1 by 5 -HT was significantly attenuated by selective $5-\mathrm{HT}_{2}$ and 5 - $\mathrm{HT}_{4}$ receptor antagonists, but not by a 5- $\mathrm{HT}_{3}$ receptor antagonist. In support, $5-\mathrm{HT}_{2}$ and 5- $\mathrm{HT}_{4}$ receptor agonists mimicked the facilitating effects of 5-HT on TRPV1 function. Downstream signaling required G-protein activation and phosphorylation as intracellularly administered GDP- $\beta$-S [ guanosine $5^{\prime}$ - 0 - $(2$ thiodiphosphate], protein kinase A inhibitors, and an A-kinase anchoring protein inhibitor significantly blocked serotonergic facilitation of TRPV1 function; $5-\mathrm{HT}_{2}$ receptor-mediated facilitation was also inhibited by a PKC inhibitor. We conclude that the facilitation of TRPV1 by metabotropic 5-HT receptor activation may contribute to hypersensitivity of primary afferent neurons in irritable bowel syndrome patients.
\end{abstract}

Key words: visceral pain; thermal hyperalgesia; DRG; serotonin receptor; capsaicin receptor; DiI

\section{Introduction}

Irritable bowel syndrome (IBS) is a chronic disorder characterized by abdominal pain and discomfort and changes in bowel habits in the absence of structural or biochemical abnormalities. IBS is prevalent, with symptoms at least transiently affecting up to one in five Americans each year, and is the second leading cause of workplace absenteeism in the United States after the common cold, resulting in estimated direct and indirect costs exceeding $\$ 30$ billion annually (Sandler et al., 2002). The mechanisms leading to the development of functional gastrointestinal disorders such as IBS are poorly understood. However, mounting evidence suggests that changes in visceral sensation (i.e., visceral hypersensitivity) play an important role in the pathogenesis of these disorders. Sensitization of peripheral sensory pathways and altered central processing (central sensitization) both contribute to visceral hypersensitivity. Although changes in ion channel expression during inflammation increase the excitability of primary

Received July 2, 2004; revised Aug. 5, 2004; accepted Sept. 1, 2004.

This work was supported by National Institutes of Health Grant NS19912.

Correspondence should be addressed to Dr. Takeshi Sugiura, Department of Pharmacology, Carver College of

Medicine, The University of lowa, Bowen Science Building, lowa City, IA 25542. E-mail: takeshi-sugiura@uiowa.edu. DOI:10.1523/JNEUROSCI.2639-04.2004

Copyright $\odot 2004$ Society for Neuroscience $\quad$ 0270-6474/04/249521-10\$15.00/0 afferent neurons, it remains unclear how peripheral mechanisms contribute to altered sensations that arise in the absence of pathology.

The gastrointestinal tract is the richest source of serotonin [5-hydroxytryptamine (5-HT)] in the body, and many studies have focused on 5-HT as a mediator of visceral sensory neuron sensitization (Gershon, 1999). Most intestinal 5-HT is stored in enteroendocrine cells, where it is released locally by mechanical or chemical stimuli and can activate intrinsic and extrinsic sensory neurons, which express a variety of 5-HT receptors. Interestingly, several recent studies have reported an increased number of enteroendocrine cells in IBS patients (Bearcroft et al., 1998; Spiller et al., 2000; Houghton et al., 2003). Furthermore, the peripherally acting $5-\mathrm{HT}_{3}$ receptor antagonist alosetron blunts visceral sensation in animal models and humans and has been used clinically in the treatment of IBS (Kozlowski et al., 2000; Camilleri et al., 2001). Although circumstantial in nature, these data raise the question whether and how 5 -HT affects visceral sensation and contributes to the development of visceral hypersensitivity.

Serotonin excites mechanosensitive afferent fibers innervating the colon through effects on the ionotropic $5-\mathrm{HT}_{3}$ as well as metabotropic 5-HT receptors (Hicks et al., 2002). Although sev- 
eral studies have demonstrated effects of metabotropic 5-HT receptors on voltage-dependent ion channels in neurons (Braha et al., 1993; Torres et al., 1995; Cardenas et al., 2001), the mechanisms by which G-protein-coupled 5-HT receptors trigger action potentials are not known (Christian et al., 1989; Cardenas et al., 1997a,b). An attractive target is the TRPV1 channel, a proton and heat-gated channel that is also activated by endogenous lipid mediators and the pungent vanilloid capsaicin. TRPV1 is present in visceral afferent neurons and is increased in inflammatory diseases of the gastrointestinal tract (Yiangou et al., 2001) and in patients with rectal hypersensitivity (Chan et al., 2003). To test the hypothesis that 5-HT receptor activation enhances TRPV1 function, we performed whole-cell patch-clamp experiments in mouse colon sensory neurons.

\section{Materials and Methods}

Male CB57BL/6 mice (20-30 gm; Harlan, Indianapolis, IN) and TRPV1 knock-out mice (TRPV1 ${ }^{-1-} ; 20-30 \mathrm{gm}$; The Jackson Laboratory, Bar Harbor, ME) were used for all experiments. Mice were fed a standard laboratory diet and maintained on a $12 \mathrm{hr}$ light/dark cycle (lights on 6:00 A.M. to 6:00 P.M.). All experimental procedures were approved by the Institutional Animal Care and Use Committee of The University of Iowa.

Labeling of colon sensory neurons. Mice were anesthetized with a mixture of ketamine $(17.5 \mathrm{mg} / \mathrm{ml})$ and xylazine $(2.5 \mathrm{mg} / \mathrm{ml} ; 5 \mu \mathrm{l} / \mathrm{gm}$, i.p. $)$, and the descending colon was exposed through a paramedian incision. One microliter of the dicarbocyanine dye 1,1'-dioctadecyl-3,3,3',3tetramethlindocarbocyanine methanesulfonate [DiI; $100 \mathrm{mg}$ in $2 \mathrm{ml}$ of dimethylsulfoxide (DMSO)] was injected into five sites in the wall of the descending colon using a Hamilton microliter syringe with a 30 guage needle. Thirty seconds after the injection, the needle was carefully removed, avoiding leakage of dye into the peritoneal cavity. The abdomen was then closed, and mice were allowed to recover. DiI injection sites were confirmed after harvesting dorsal root ganglia (DRGs), and DiI was located in sites $\sim 10-25 \mathrm{~mm}$ from the anus.

Cell preparation. Mice were anesthetized with ketamine/xylazine (as above), killed by cervical dislocation, and the L6, S1, and S2 DRGs were quickly removed bilaterally under a dissection microscope. DRGs were transferred into ice-cold culture media and minced with a surgical blade. The tissue was incubated in Neurobasal-A media (Invitrogen, Carlsbad, CA) containing collagenase (type $1 \mathrm{~A} ; 2 \mathrm{mg} / \mathrm{ml}$ ), trypsin (type III; $1 \mathrm{mg}$ / $\mathrm{ml}$ ), and $3 \mathrm{~mm} \mathrm{CaCl}_{2}$ at $37^{\circ} \mathrm{C}$ for $50 \mathrm{~min}$. The tissue fragments were then gently triturated with a sterile Pasteur pipette coated with silicon and centrifuged at $800 \mathrm{rpm}$ for $5 \mathrm{~min}$. DRG neurons were resuspended in Neurobasal-A supplemented with 5\% B27 supplement, $0.25 \%$ L-glutamine (200 mM), and 1\% penicillin-streptomycin (all from Invitrogen), plated on poly-D-lysine-coated glass coverslips, and incubated for $2-10 \mathrm{hr}$ at $37^{\circ} \mathrm{C}$ in a $95 \% / 5 \%$ air $/ \mathrm{CO}_{2}$ atmosphere saturated with water vapor.

Whole-cell recordings. Patch pipettes were prepared using borosilicate glass (PG52151-4; World Precision Instruments, Sarasota, FL) with a tip resistance of 2-5 $\mathrm{M} \Omega$ after fire-polishing. They were filled with an internal solution containing (in mM) $100 \mathrm{KCl}, 10$ EGTA, $40 \mathrm{HEPES}, 5 \mathrm{MgCl}_{2}$, and $1 \mathrm{Na}_{2} \mathrm{ATP}$, adjusted to $\mathrm{pH} 7.4$ with $\mathrm{KOH}$. Extracellular solutions contained (in mM) $128 \mathrm{NaCl}, 5.4 \mathrm{KCl}, 1.8 \mathrm{CaCl}_{2}, 5 \mathrm{MgCl}_{2}, 5.55$ glucose, and 20 HEPES. For solutions below pH 4.5, HEPES was exchanged with $20 \mathrm{~mm}$ MES [2-( $\mathrm{N}$-morpholino)-ethanesulfonic acid], $\mathrm{pH}$ adjusted with $\mathrm{NaOH}$ or $\mathrm{HCl}$. In calcium-free experiments, $\mathrm{CaCl}_{2}$ was omitted, and 5 mM EGTA was added to the standard solution.

Solutions were applied through a three-barreled glass tubing manifold (inner diameter, $700 \mu \mathrm{m}$ ) located $\sim 150 \mu \mathrm{m}$ from the cell, except for thermal tests. Rapid solution exchange was achieved within $20 \mathrm{msec}$ by movement of the manifold (SF-77B; Warner Instruments, Hamden, $\mathrm{CT}$ ). To avoid desensitization to capsaicin or protons, we allowed $1 \mathrm{~min}$ between solution exchanges, unless noted otherwise. Heat-sensitive currents were evoked once in each cell by superfusing preheated solutions, increasing the bath temperature at a rate of $\sim 1.0-1.5^{\circ} \mathrm{C} / \mathrm{sec}$. The temperature of the bath solution was monitored with a thermistor placed $\sim 100 \mu \mathrm{m}$ from the cell (accuracy, $\pm 0.1^{\circ} \mathrm{C}$ ). Colon sensory neurons were identified by their red-orange color under Hoffman Contrast Optics $(400 \times)$ in fluorescent light with a rhodamine filter (excitation wavelength, $546 \mathrm{~nm}$; barrier filter, $580 \mathrm{~nm}$ ). Only DiI-labeled cells were studied. Whole-cell voltage-clamp and current-clamp recordings were performed with an Axopatch 200B amplifier (Axon Instruments, Foster City, CA). Recordings were filtered at $5 \mathrm{kHz}$ and digitized at $1 \mathrm{kHz}$ using a Digidata 1320A interface (Axon Instruments). For current-clamp experiments, only neurons with a stable resting membrane potential of at least $-40 \mathrm{mV}$ were included in the study. Unless stated otherwise, all experiments were performed at room temperature.

Immunohistochemistry. Acutely dissociated DRG cells (see above) were fixed in $4 \%$ paraformaldehyde in $0.1 \mathrm{~m}$ phosphate buffer for $10 \mathrm{~min}$. After washing with $0.01 \mathrm{~m}$ PBS, the specimens were incubated in 3\% normal goat serum (NGS; Sigma, St. Louis, MO) for $30 \mathrm{~min}$ at room temperature to reduce nonspecific binding and then with an N-terminal specific polyclconal TRPV1 antibody (rabbit anti-capsicin receptor at a dilution of 1 $\mu \mathrm{g} / \mathrm{ml}$; Calbiochem, La Jolla, CA) in $3 \%$ NGS at $4^{\circ} \mathrm{C}$ overnight. Specimens were then washed with $0.01 \mathrm{M}$ PBS and incubated with goat antirabbit IgG (1:200; Alexa Fluoro 488; Molecular Probes, Eugene, OR) in $3 \%$ NGS for $2 \mathrm{hr}$ at room temperature. After washing, specimens were mounted with Fluoromount G (Electron Microscopy Sciences, Washington, PA) and coverslipped. Control experiments were performed by incubating without primary antibody, or by preincubating primary antibody with the antigenic peptide (capsaicin receptor control peptide; Calbiochem) for $4 \mathrm{hr}$ at $4^{\circ} \mathrm{C}$. Slides were examined with a fluorescence microscope (Optiphot; Nikon, Tokyo, Japan) equipped with separate filters. Images were captured with a model 2.3.1 SPOT digital camera (Diagnostic Instruments, Sterling Heights, MI).

Chemicals. 5-HT, ( \pm )-1-(2,5-dimethoxy-4-iodophenyl)-2-aminopropane hydrochloride (DOI), 5-methoxytryptamine (5-MeOT), (1-butyl-4piperidinyl)methyl-8-amino-7-chloro-1,4-benzodioxane-5-carboxylate hydrochloride (SB204070), guanosine 5'-O-(2-thiodiphosphate) (GDP$\beta$-S), $N$-[2-(p-bromocinnamylamino)ethyl]-5-isoquinolinesulfonamide dihydrochloride (H-89), $\mathrm{N}$-amidino-3, 5-diamino-6-chloropyrazinecarboxamide hydrochloride (amiloride), $N$-[2-(4-chlorophenyl)ethyl]-1,3,4,5tetrahydro-7,8-dihydroxy-2H-2-benzazepine-2-carbothioamide (capsazepine), and 8-methyl- $N$-vanillyl-trans-6-nonenamide (capsaicin) were purchased from Sigma. 3-[2-[4-(4-Fluorobenzoyl)-1-piperidinyl]ethyl]$2,4\left[1 \mathrm{H},{ }^{3} \mathrm{H}\right]$-quinazolinedione tartrate (ketanserin), $\alpha$-methyl-5hydroxytriptamine maleate $(\alpha \mathrm{Me}-5-\mathrm{HT})$, tropanyl 3,5-dichlorobenzoate (MDL-72222), ( \pm )-4-amino-5-chloro- $N$-[1-[(3R*,4S*)-3-(4-fluorophenoxy)propyl]-3-methoxy-4-piperidinyl]-2-methoxybenzamide (cisapride), 1-methyl-1 $H$-indole-3-carboxylic acid, and [1-[2-[(methylsulfonyl)amino] ethyl]-4-piperidinyl]methyl ester (GR133808) were purchased from Tocris (Ellisville, MO). The protein kinase A (PKA) inhibitor 6-22 amide, AKAP inhibitor peptide (St-Ht31), and calphostin C were purchased from Calbiochem. All chemicals were dissolved in distilled water or DMSO and applied in a final concentration of $<0.1 \%$.

Data analysis. Data are expressed as means \pm SEM. The software package pCLAMP9.0 (Axon Instruments) and SigmaPlot 8.02 and SigmaStat 2.03 (SPSS, Chicago, IL) were used for data acquisition and analysis. Concentration-response curves were fitted by the Hill equation, $I=$ $I_{\text {mini }}+\left(I_{\max }-I_{\text {mini }}\right) \times[X]^{n} /\left(\left[\mathrm{EC}_{50}\right]^{n}+[X]^{n}\right)$, where $I$ is the current amplitude ratio triggered by $\mathrm{pH} 5.5$ before and after a given serotonin concentration, $[X ; 5-\mathrm{HT}]$, or the current density at different proton concentrations, $\left[X ; \mathrm{H}^{+}\right] ; I_{\max }$ or $I_{\operatorname{mini}}$ is the maximum or minimum response of the cell; $n$ is the Hill slope; and $\mathrm{EC}_{50}$ is the concentration eliciting a half-maximal response.

Data were compared using Student's two-tailed unpaired or paired $t$ tests or repeated-measures, one-way or two-way ANOVA as appropriate. Statistical significance was determined at $p<0.05$.

\section{Results}

Temperature-dependent activation of colon sensory neurons In wild-type mice, temperature ramps depolarized all colon sensory neurons tested, triggering bursts of action potentials near $42^{\circ} \mathrm{C}$ (Fig. 1a,b). When we tested the capsaicin sensitivity of wildtype neurons after temperature ramps, all of the 13 cells tested 

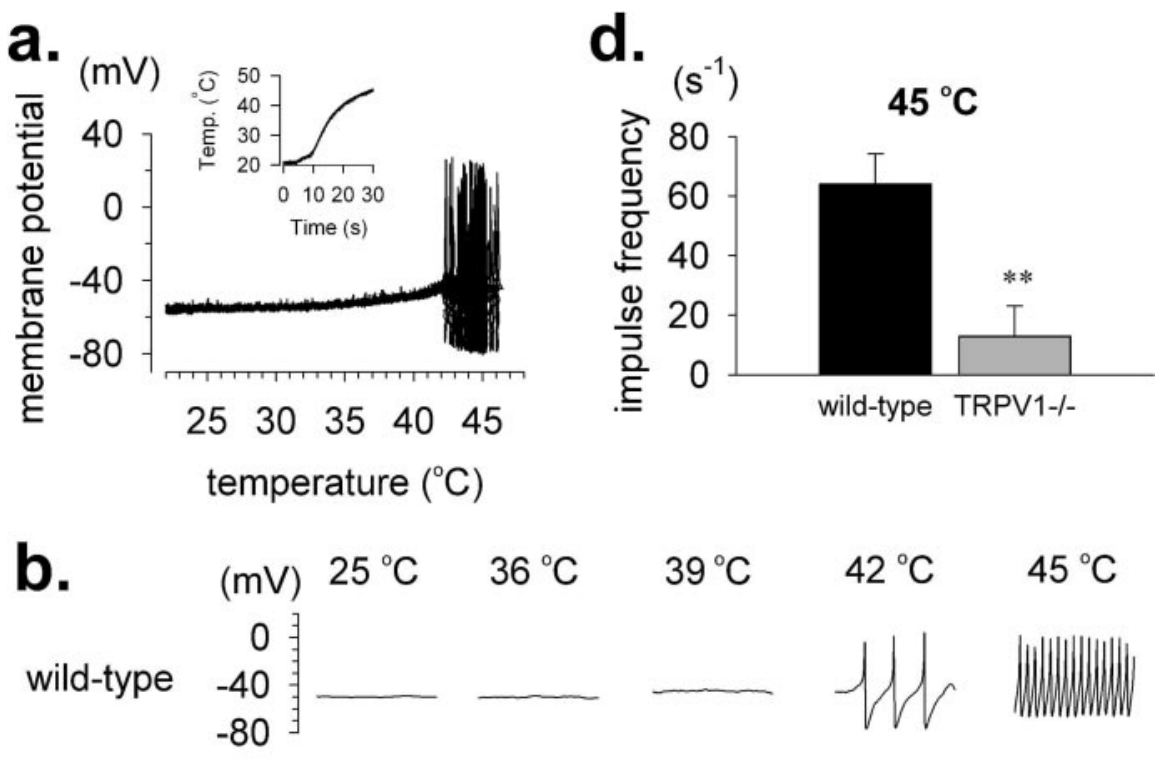

$36{ }^{\circ} \mathrm{C}$
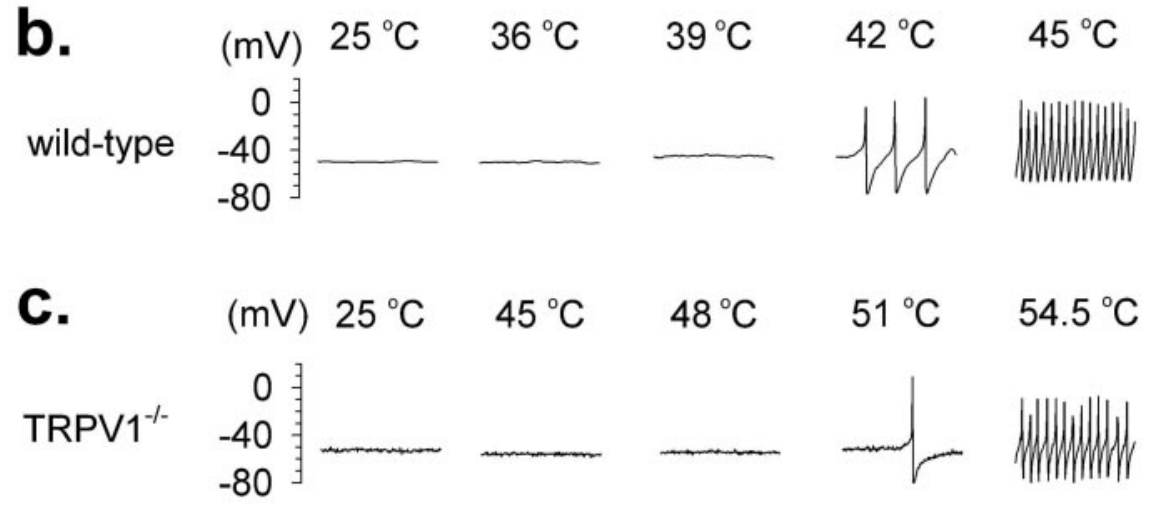

$48^{\circ} \mathrm{C}$
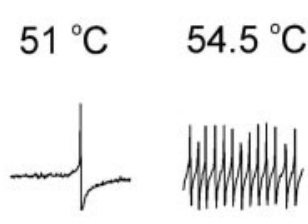

min after the first application of capsaicin $(1 \mu \mathrm{M})$, the response was $77 \pm 4 \%(n=6)$ of the first response to capsaicin (Fig. $2 b$ ) $(F=50.11 ; p<0.001)$. Only 6 of 42 colon sensory neurons tested did not respond to capsaicin. In two of these capsaicininsensitive neurons, we tested the response to temperature and only saw inward currents when the bath temperature exceeded $50^{\circ} \mathrm{C}$ (data not shown). None of the neurons from TRPV $1^{-/-}$mice responded to capsaicin $(10 \mu \mathrm{M} ; n=4)$ (Fig. $2 f)$.

Consistent with previous reports, all capsaicin-sensitive colon sensory neurons tested also responded to protons with slowly activating and sustained inward currents (Fig. 2b,c,f) (Caterina et al., 1997). This acid-evoked current did not desensitize significantly when neurons were repeatedly stimulated in the absence of extracellular calcium $(F=0.57 ; p=$ $0.7)$. However, in the presence of extracellular calcium, repetitive proton applications triggered current responses that desensitized significantly $(F=2.96 ; p<$ 0.05) (Fig. 2b). The TRPV1 blocker capsazepine $(10 \mu \mathrm{M})$ significantly attenuated the sustained acid-evoked current (Fig. $2 c$, middle; $d)$. In contrast, amiloride (200 $\mu \mathrm{M})$ did not significantly affect the acidevoked inward current (Fig. $2 c$, right; $e$ ), suggesting that proton-sensitive currents in colon sensory neurons are primarily carried through TRPV1 channels. We therefore examined acid-evoked currents in colon sensory neurons from TRPV $1^{-1-}$ animals. Consistent with the pharmaco-

Figure 1. Temperature-dependent excitability of colon sensory neuron from wild-type and TRPV $1^{-/-}$mice. $a$, Representative responses in current-clamp recording mode to a temperature ramp. Thermal stimuli evoked depolarization and action potentials. $b, c$, Representative records from wild-type $(b)$ and TRPV1 ${ }^{-1-}(c)$ neurons at different temperatures show action potential generation at temperatures above $42^{\circ} \mathrm{C}$ in wild-type neurons and above $50^{\circ} \mathrm{C}$ in TRPV $1^{-1-}$ neurons. $d$, Mean $\pm S E M$ action potential frequency of colon afferent neurons in response at $45^{\circ} \mathrm{C}$ in wild-type (black bar; $\left.n=8\right)$ and TRPV ${ }^{-1-}$ (gray bar; $\left.n=6 ; t=3.49 ;{ }^{* *} p<0.01\right)$ mice.

depolarized in response to $10 \mu \mathrm{M}$ capsaicin. Although capsaicin did not trigger action potential in all cells when given after the initial heat stimulus, it elicited spikes when given to untreated cells. In TRPV $1^{-1-}$ mice, temperatures below $50^{\circ} \mathrm{C}$ typically generated few action potentials, presumably through activation of TRPV2 or other temperature-sensitive currents (Fig. 1c), and impulse frequency at $45^{\circ} \mathrm{C}$ was significantly lower in TRPV $1^{-1-}$ mice than in C57BL/6 mice $(t=3.49 ; p<0.01)$ (Fig. $1 d)$.

\section{Characterization of TRPV1 function in colon sensory neurons}

Inward current in colon DRG neurons developed at $\sim 42^{\circ} \mathrm{C}$ with an extremely steep temperature dependency (Fig. 2a), consistent with our current-clamp data and previous reports in DRG neurons (Sugiura et al., 2002). The mean threshold temperature for activation (defined as the intersection where two lines approximating the stable baseline current and clearly increasing temperature-dependent current) was $41.8 \pm 0.7^{\circ} \mathrm{C}$. Similar to results obtained with current clamp, colon DRG neurons also responded to subsequent challenge with capsaicin. The amplitude of the capsaicin-evoked current was smaller than that of the heat-evoked current because of desensitization of TRPV1 activation. When given to naive cells, the peak current density evoked by capsaicin $(409.8 \pm 33.0 \mathrm{pA} / \mathrm{pF} ; n=3)$ was greater than that of heat $(249.1 \pm 60.8 \mathrm{pA} / \mathrm{pF} ; n=6)$. The capsaicin-evoked current showed a lasting desensitization; when applied a second time 1 logical data, cells from knock-out mice did not show significant sustained-type current responses to protons (Fig. $2 f$ ). To further characterize the properties of acid-evoked currents, we examined the $\mathrm{pH}$ dependence of these currents using solutions with $\mathrm{pH}$ between 7.0 and 3.5. We allowed $1 \mathrm{~min}$ between each $5 \mathrm{sec}$ application to prevent desensitization. As shown in the left trace of Figure $2 f$, the current is activated at $\mathrm{pH} 5.5$ with half-activation at pH $4.57 \pm 0.07$ (Fig. $2 f$, right $)(n=8)$.

To obtain additional evidence that colon sensory neurons express TRPV1, we examined immunoreactivity (IR) for TRPV1 in acutely dissociated DRG neurons. Figure $3 a$ shows double staining of retrograde tracer that was injected into the colon wall and TRPV1-like IR in a DRG neuron. In control experiments performed by omitting the primary antibody (Fig. $3 c$ ) or preincubating the primary antibody with blocking peptide (Fig. $3 d$ ), immunohistochemical staining of DRG cells for TRPV1-like IR was abolished.

\section{5-HT enhances excitability of colon sensory neurons through TRPV1 activation}

To test the working hypothesis, we next examined the effect of 5-HT ( $1 \mu \mathrm{M} ; 2$ min; bath application) on heat-evoked depolarization and action potential firing in colon sensory neurons. Although neither vehicle nor 5-HT altered resting membrane potential $(-49.4 \pm 1.8 \mathrm{mV}$ and $-46.6 \pm 1.5 \mathrm{mV}$ in vehicle- and 
5-HT-treated neurons, respectively; $n=$ 8/group), responses to heat were significantly enhanced in the presence of 5-HT in DRG neurons from C57BL/6 mice (Fig. $4 a, c)$. Notably, action potentials were generated by heat at temperatures below core body temperature (Fig. $4 c$, broken vertical line) in the presence of 5-HT. In contrast, there was no significant temperature dependency of responses in TRPV $1^{-1-}$ mice or effect of 5-HT within the temperature range tested (Fig. $4 b, d$ ).

In voltage-clamp experiments, neither vehicle nor $1 \mu \mathrm{M}$ 5-HT triggered current responses. In contrast to the desensitization seen with repeated capsaicin application (Fig. 2b), pretreatment with 5-HT (1 $\mu \mathrm{M} ; 50 \mathrm{sec}$ ) between the first and second application of capsaicin not only prevented the desensitization but significantly enhanced the response to the second application of capsaicin more than twofold relative to the typically desensitized response to a second application of capsaicin (Fig. 5a). Similarly, 5-HT enhanced responses to heat. Defining the threshold temperature $\left(T_{\mathrm{t}}\right)$ as the intersection where two lines approximating the stable baseline current and the clearly increasing temperature-dependent current cross ( $\mathrm{Su}$ giura et al., 2002), 5-HT ( $1 \mu \mathrm{M} ; 2$ min; bath application) pretreatment significantly reduced the mean $T_{\mathrm{t}}$ to $38.1 \pm 1.2^{\circ} \mathrm{C}(n=7$; $t=-2.50 ; p<0.05)$ from a control $41.8 \pm$ $0.7^{\circ} \mathrm{C}(n=6)$ (Fig. $\left.4 b\right)$. Likewise, the acidactivated current, $\mathrm{pH} 5.5$, was also significantly enhanced by pretreatment with 5-HT ( $1 \mu \mathrm{M} ; 50 \mathrm{sec}$ ) (Fig. 5c). Consistent with results obtained in neurons from TRPV1 ${ }^{-/-}$mice, the TRPV1 receptor antagonist capsazepine $(10 \mu \mathrm{M})$ significantly attenuated enhancement of the acidactivated current by 5-HT (to $19.6 \pm$ $3.8 \% ; n=3$ ) relative to $\mathrm{pH} 5.5$ application in the absence of the antagonist (100.1 \pm $6.8 \% ; n=8 ; t=6.86 ; p<0.001$ ) (Fig. 5c). To determine the concentration dependency of the enhancing effect of 5-HT, we examined the acid-activated current, $\mathrm{pH}$ 5.5, after exposure of cells to various 5-HT concentrations between $1 \mathrm{~nm}$ and $10 \mu \mathrm{M}$, testing each cell only once to prevent desensitization to 5-HT. Greater concentrations of 5-HT were given in the presence of MDL72222 (3 $\mu \mathrm{M})$, a selective $5-\mathrm{HT}_{3}$ receptor antagonist, to block activation of $5-\mathrm{HT}_{3}$ receptors, which caused a decrease in serotonergic enhancement of acid-evoked currents (30 and 100 $\mu \mathrm{M}$; data not shown). Within the range between $1 \mathrm{nM}$ and $10 \mu \mathrm{M}$, the effect of 5-HT was concentration dependent, with an $\mathrm{EC}_{50}$ value of $2.2 \mu \mathrm{M}$ and Hill coefficient of 1.1 (Fig. $5 d$ ). Figure $5 e$ shows the magnitude and duration of 5-HT $(1 \mu \mathrm{M})$ enhancement of the acid-activated current, $\mathrm{pH} 5.5 ; 5-\mathrm{HT}$ was applied once for $50 \mathrm{sec}$ after the first application of acidic solution. The
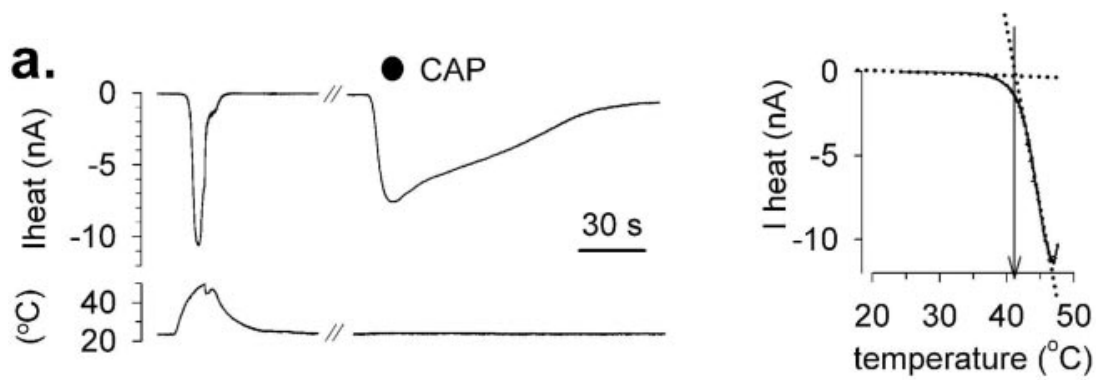

b.
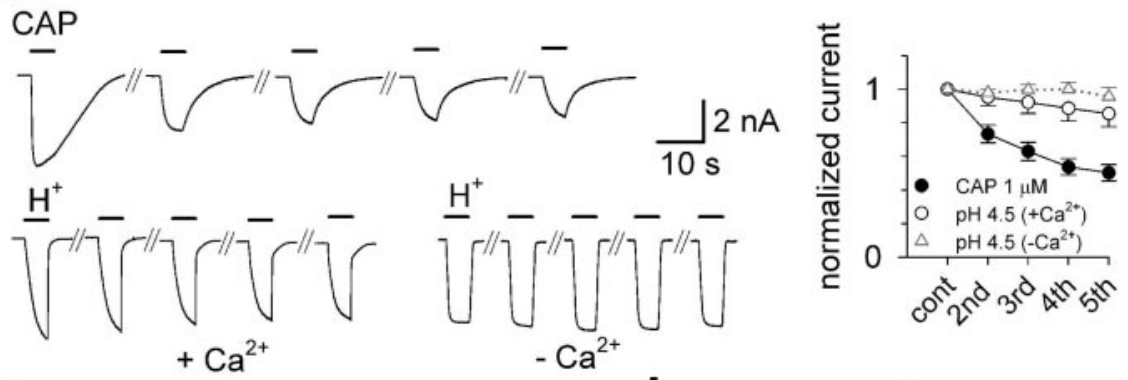

C.

$\mathrm{pH} 4.5$

d.

e.
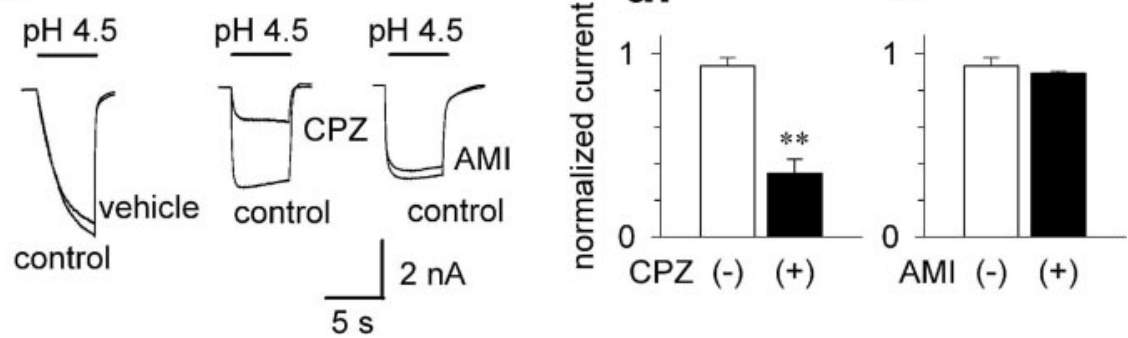


Figure 2. Characteristics of TRPV1 function in colon afferent neurons. $a$, Representative records of heat-evoked $\left(I_{\text {heat }}\right)$ and capsaicin-evoked (CAP; $10 \mu \mathrm{m}$; filled circle) currents. The right panel shows the threshold temperature for heat activation using heat ramps as illustrated in the left panel (see Materials and Methods for details). $b$, Repeat application of capsaicin (CAP; $1 \mu \mathrm{M}$; $5 \mathrm{sec}, 1 \mathrm{~min}$ interval; $n=6 ; F=50.11 ; p<0.001)$ and acid $\left(\mathrm{H}^{+} ; \mathrm{pH} 4.5 ; n=5 ; F=2.96 ; p<0.05\right)$ in the presence of extracellular calcium are associated with significant desensitization of current responses as shown in samples tracings (left); data are summarized in a graph (right). Acid-evoked currents did not desensitize significantly in calcium-free solutions $\left(-\mathrm{Ca}^{2+}\right) . C$, Representative records of acid-evoked currents, pH 4.5, in the presence of vehicle, capsazepine (CZP; $10 \mu \mathrm{m})$, or amilorlide (AMl; $200 \mu \mathrm{M})$. Data are summarized for vehicle $(n=6)$, capsazepine $\left(n=9 ; t=5.81 ;{ }^{* *} p<0.01\right)$, and amiloride $(n=9 ; t=0.93$; not significant) in $d$ and $e$, respectively. $f$, Representative records of acid-evoked sustained currents in wild-type (left) and TRPV1 $^{-1-}$ (middle) mice. None of the four TRPV1 ${ }^{-/-}$neurons tested responded to capsaicin (CAP; bottom record; middle). Data for current responses to different proton concentrations are summarized in the right panel for wild-type mice (filled circles; $n=8$ ) and TRPV1 ${ }^{-1-}$ mice (unfilled circles; $n=11$ ).

effect of the single application of 5 -HT lasted at least $7 \mathrm{~min}$ $(n=7 ; p<0.05$; vs vehicle, $n=7)$. When tested at areater concentration in the same protocol, 5-HT ( $3 \mu \mathrm{M})$ enhanced the $\mathrm{pH}$-activated current for at least $20 \mathrm{~min}$ (10 min: $2.11 \pm$ 0.60 -fold, $n=6 ; 20 \mathrm{~min}: 1.97 \pm 0.48$-fold, $n=3$ ). As shown in Figure $5 f$, 5-HT $(1 \mu \mathrm{M})$ significantly shifted the $\mathrm{pH}$ of halfactivation from $4.57 \pm 0.07(n=8)$ to $5.14 \pm 0.09(n=7 ; t=$ 5.06; $p<0.001)$ and Hill coefficient of $1.69 \pm 0.35$ and $3.86 \pm$ 0.45 , respectively. 

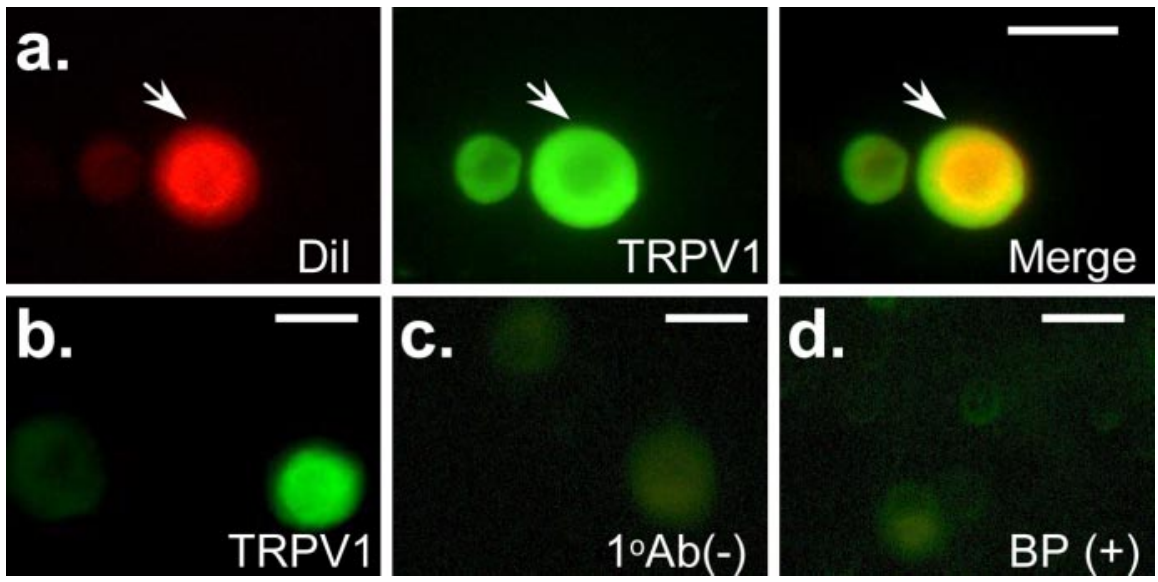

Figure 3. Immunohistochemical evidence of TRPV1expression in colon DRG neurons. $a$, The left panel shows a Dil-labeled neuron visualized with fluorescent light at an excitation wavelength of $546 \mathrm{~nm}$. When excited with fluorescent light with a wavelength of $488 \mathrm{~nm}$, two cells with TRPV1-like IR can be seen in the same field (middle). The merged image in the right panel demonstrates the colocalization of the retrograde label Dil and TRPV1-like IR in one neuron marked by the arrow. TRPV1-like IR ( $b$ ) was not detected in the absence of the primary antibody $\left[1^{\circ} \mathrm{Ab}(-) ; c\right]$ or after preincubation of the primary antibody with the blocking peptide $[\mathrm{BP}(+) ; d]$. Scale bar, $30 \mu \mathrm{m}$. a.

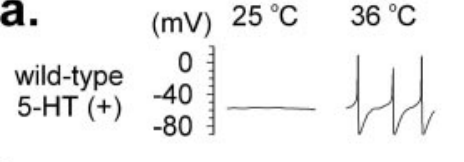

b. $\left.\begin{array}{lr}\text { TRPV1 } & 0 \\ 5-\mathrm{HT}(+) & -40 \\ & -80\end{array}\right]^{-*}$

c.

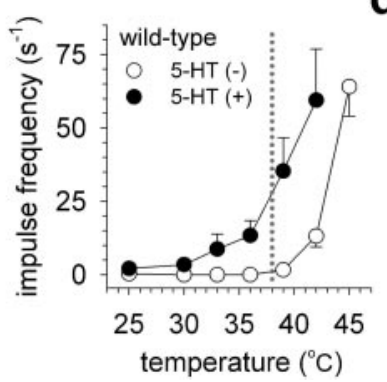

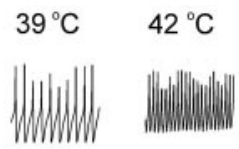

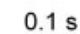

Figure 4. 5-HT enhances excitability of a colon sensory neuron in response to thermal stimulation. Representative records from wild-type $(a)$ and TRPV1 ${ }^{-1-}(b)$ neurons at different temperatures in the presence of 5 - $\mathrm{HT}$ ( $1 \mu \mathrm{m}$ pretreatment for $2 \mathrm{~min}$ ) are shown. Action potentials in neurons from wild-type mice were generated at significantly lower temperatures $\left(36^{\circ} \mathrm{C}\right)$ in the presence of 5-HT ( $c$; compare with Fig. $1 b$ ). In neurons from TRPV1 ${ }^{-1-}$ mice, action potentials were generated only at temperatures $>45^{\circ} \mathrm{C}$ in the presence of $5-\mathrm{HT}$. Temperaturedependent action potential firing after exposure to vehicle (unfilled symbols) or $1 \mu \mathrm{m}$ 5-HT (filled symbols) is summarized for wild-type $(c)$ and TRPV1 ${ }^{-1-}$ mice $(d)$. Compared with vehicle, 5 -HT significantly shifted the response to temperature in neurons from wild-type mice (5-HT, $n=8$; vehicle, $n=8 ; F=19.40 ; p<0.001)$. The dotted vertical line in c indicates the normal core temperature of wild-type mice.

\section{Pharmacology of serotonergic enhancement of TRPV1 function}

Visceral sensory neurons express several 5-HT receptors (Grundy et al., 1998; Hicks et al., 2002; Mazzia et al., 2003), and we therefore examined the role of different 5 -HT receptors in the modulation of TRPV1 function using pharmacological tools. As described above, concentrations of 5 -HT $\geq 1.0 \mu \mathrm{M}$ did not affect resting membrane potential or baseline currents. However, $3 \mu \mathrm{M}$
5-HT evoked a slowly activating current in seven of eight colon sensory neurons, which increased in amplitude and showed a more rapid activation and desensitization at higher concentrations of 5-HT, consistent with the expression of the ligand-gated $5-\mathrm{HT}_{3}$ receptor (Fig. $6 a$ ). To confirm this, we used the selective $5-\mathrm{HT}_{3}$ receptor antagonist MDL72222 $(0.6 \mu \mathrm{M})$, which completely and reversibly blocked the inward current produced by $10 \mu \mathrm{M}$ 5 -HT in colon neurons $(8.4 \pm 3.6 \%$ of control; $n=6 ; t=25.3 ; p<0.001$ ) (Fig. 6b). MDL72222 (0.6 $\mu \mathrm{M})$, however, did not affect serotonergic enhancement of the acid-activated inward current in colon sensory neurons (Fig. $6 c$ ), revealing that metabotropic 5-HT receptors mediate this effect.

Six families of G-protein-coupled 5-HT receptors with several members have been characterized (Barnes and Sharp, 1999). Of those, $5-\mathrm{HT}_{1}, 5-\mathrm{HT}_{2}$, and $5-\mathrm{HT}_{4}$ have been identified in DRG neurons (Nicholson et al., 2003). Because $5-\mathrm{HT}_{1}$ receptors preferentially couple to phosphodiesterase and $5-\mathrm{HT}_{2}$ and $5-\mathrm{HT}_{4}$ receptors couple to $\mathrm{G}_{\mathrm{s}}$ and $\mathrm{G}_{\mathrm{q} / 11}$, we focused on $5-\mathrm{HT}_{2}$ and $5-\mathrm{HT}_{4}$ receptors using selective receptor agonists and antagonists. Colon sensory neurons were pretreated with ketanserin (a 5- $\mathrm{HT}_{2}$ receptor-selective antagonist) or $5-\mathrm{HT}_{4}$ receptor-selective antagonists SB204070 or GR113808 before administration of 5-HT $(1 \mu \mathrm{M})$ for $50 \mathrm{sec}$. No detectable effects of these antagonists (all at $10 \mu \mathrm{M}$ ) were observed (data not shown). In contrast to the $5-\mathrm{HT}_{3}$ receptor-selective antagonist MDL72222 (Fig. 6c), ketanserin, SB204070, and GR113808 each significantly attenuated 5-HT-induced enhancement of the acidactivated current, $\mathrm{pH} 5.5$, in the presence of 5-HT (Fig. 7a,c). Moreover, $5-\mathrm{HT}_{2}$ receptor agonists DOI and $\alpha$ Met-5-HT or the $5-\mathrm{HT}_{4}$ receptor agonist 5-MeOT mimicked 5-HT-mediated facilitation of TRPV1 function in colon sensory neurons (Fig. $7 b, d)$. Similar to 5 -HT, the effect of 5-MeOT was attenuated by SB204070 ( $n=4$; data not shown).

To determine whether 5-HT-mediated enhancement of TRPV1 function involves activation of G-proteins in colon sensory neurons, we examined the effects of GDP- $\beta-S(0.5 \mathrm{~mm}$ within the internal pipette solution). In the presence of GDP- $\beta-S$, 5-HT-induced enhancement of the acid-activated current was significantly reduced (Fig. $8 a, d$ ). Because $5-\mathrm{HT}_{2}$ and $5-\mathrm{HT}_{4}$ receptors are linked with either $\mathrm{G}_{\mathrm{q} / 11}$, which is known to stimulate phospholipase C (PLC) and result in activation of PKC, or $G_{s}$, which is known to stimulate adenylate cyclase and result in activation of PKA, respectively, we examined the involvement of protein kinase pathways by adding selective PKA or PKC inhibitors to the internal pipette solution. The PKA inhibitors $\mathrm{H}-89$ and $\mathrm{PKI}_{6-22}$ blocked the 5-HT-induced enhancement of TRPV1 function (Fig. 8a,d). Similarly, the PKC inhibitor calphostin C reduced serotonergic enhancement of TRPV1 function (Fig. $8 a, d)$.

To examine the contribution of PKA and PKC in 5-HTmediated facilitation of TRPV1 function in more detail, we tested selective $5-\mathrm{HT}_{2}$ or $5-\mathrm{HT}_{4}$ agonist-mediated facilitation. Consistent with the finding linking the $5-\mathrm{HT}_{2}$ receptor with $\mathrm{PLC}$ and $\mathrm{PKC}$, the selective $5-\mathrm{HT}_{2}$ receptor agonist DOI-mediated enhancement of TRPV1 function was attenuated by calphostin $\mathrm{C}$ 
(Fig. 8b,e). Interestingly, $\mathrm{PKI}_{6-22}$ and A-kinase anchoring protein inhibitor StHt-31 also significantly attenuated DOImediated enhancement of TRPV1 function (Fig. 8b,e). Similarly, enhancement of TRPV1 by the selective $5-\mathrm{HT}_{4}$ receptor agonist 5-MeOTwas blocked by $\mathrm{PKI}_{6-22}$ and AKAP inhibitor peptide, but not by calphostin $\mathrm{C}$, consistent with the known coupling between the $5-\mathrm{HT}_{4}$ receptor and adenylate cyclase (Fig. $8 c, f$ ).

\section{Mouse core temperature}

Considering the shift in temperaturedependent action potential firing of colon sensory neurons by 5 -HT, we measured colon temperature in $\mathrm{C} 57 \mathrm{BL} / 6$ mice. The rectally obtained core temperature of $37.8 \pm 0.3^{\circ} \mathrm{C}(n=5)$ falls within the range of a significant increase in spontaneous firing because of facilitation of TRPV1 function.

\section{Discussion}

The extrinsic, afferent innervation of the gastrointestinal tract conveys information to the CNS that gives rise to the sensations of pain and discomfort. Most afferent input from the viscera, however, is not consciously perceived under normal circumstances. However, patients with functional disorders such as IBS, in which pain and discomfort are common, experience these sensations in the absence of noxious intensities of stimulation or apparent pathology, suggesting the presence of hypersensitivity. In whole-cell patch-clamp recordings from identified colon sensory neurons, we demonstrated a significant leftward shift in the temperature sensitivity of TRPV1 by 5-HT to include activation of TRPV1 at normal body temperature. This suggests that 5 -HT release from enteroendocrine cells by normal mechanical or chemical stimuli could play a role in development of the altered sensations that arise in IBS patients.

Although we did not use heterologous expression systems, the present results are interpreted in the context of TRPV1 (proton, heat, and capsaicin activation) and supported by use of TRPV $1^{-/-}$mice, previously reported to exhibit attenuated thermal responsiveness (Caterina et al., 2000; Davis et al., 2000) and immunocytochemistry. Although there are many receptors that transduce thermal energy (Patapoutian, 2003), enhancement of responses to temperature, protons, and capsaicin by 5 -HT was absent in TRPV $1^{-1-}$ mice, pointing at an important role of this channel in modulating colon sensory neuron excitability.

Consistent with documentation of TRPV1-like IR in mouse colon neurons (Robinson et al., 2004), >80\% of the colon DRG neurons tested here responded to capsaicin or generated slowly
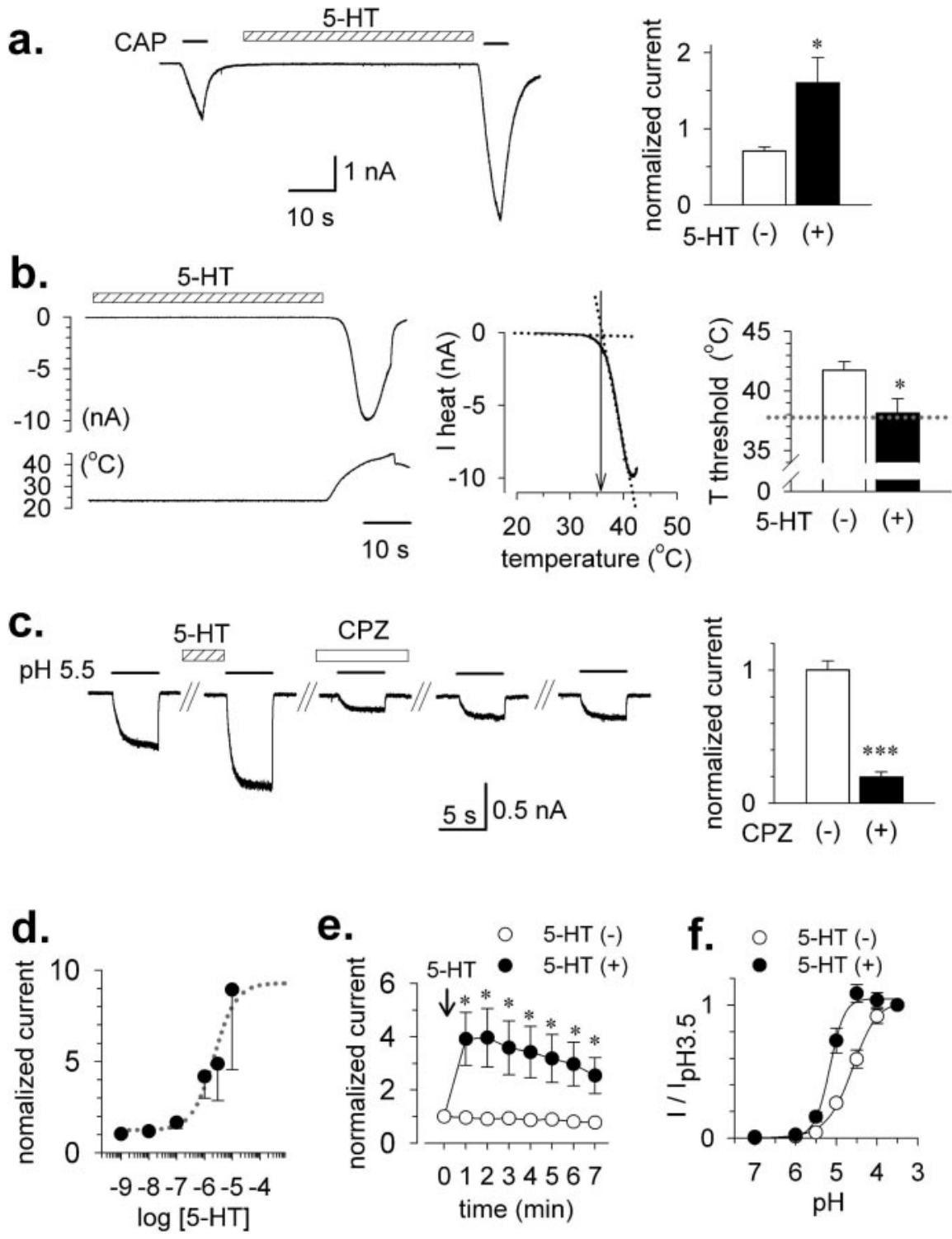

Figure 5. 5-HT enhances capsaicin-, heat-, and proton-evoked currents in colon sensory neurons. $a$, Representative records of the current evoked by capsaicin (100 nm) after exposure to 5-HT (1 $\mu \mathrm{m}$; left). Summary data for the second response to capsaicin, normalized to the initial response, are shown to the right (filled bar: $1 \mu \mathrm{m} 5$-HT, $n=7$; unfilled bar: vehicle, $n=6 ; t=2.46$; ${ }^{*} p<$ 0.05). b, Representative heat-evoked current after 2 min pretreatment with 5 - HT (1 $\mu \mathrm{m}$ ). The middle record shows the threshold temperature determined in this neuron; data are summarized in the right panel for 5 -HT (filled bar; $n=7$ ) and vehicle (unfilled bar; $n=6 ; t=2.50 ;{ }^{*} p<0.05,5$-HT vs vehicle). The dotted vertical line indicates the normal core temperature of wild-type mice. c, Representative records of acid-evoked currents before and after exposure to 5 -HT (1 $\mu \mathrm{m})$. Compared with exposure to vehicle (right; unfilled bar; $n=8)$, the TRPV1 antagonist capsazepine (CPZ; $10 \mu \mathrm{m}$; filled bar) significantly attenuated serotonergic facilitation of the acid-evoked current $\left(n=3 ; t=6.86 ;^{* * *} p<0.001\right)$. $d$, The normalized current in response to protons, pH 5.5, is plotted as a function of 5 -HT concentration before the second acid stimulus and fitted to the Hill equation (data from 47 cells). MDL72222 (3 $\mu \mathrm{m})$ was added in experiments with $10 \mu \mathrm{m}$ of 5-HT. $e$, The time course of changes in the acid-evoked current after 1 min exposure to 5-HT (1 $\mu$ m; filled circles; $n=7)$ or vehicle (unfilled circles; $n=7)\left({ }^{*} p<0.05\right)$. $f$, pH dependence of the acid-evoked current after 1 min exposure to 5 -HT (1 $\mu$ m; filled circles; $n=7$ ) or vehicle (unfilled circles; $n=8$ ). The data were fitted to the Hill equation; the difference in $\mathrm{pH}_{50}$ between the groups was significant $(t=5.06 ; p<0.001)$.

sustained currents in response to acid that were blocked by capsazepine. This differs from results obtained in unidentified DRG neurons, in which $<50 \%$ of cells responded to capsaicin (Dirajlal et al., 2003), consistent with studies showing mRNA or IR for TRPV1 in $<50 \%$ of DRG neurons (Caterina et al., 1997; Michael and Priestley 1999; Robinson et al., 2004). Similarly, the response to acid appears to be distinct between identified visceral DRG neurons and unidentified DRG neurons. In colon sensory neurons from $\mathrm{C} 57 \mathrm{BL} / 6$ mice, protons almost exclusively activated 


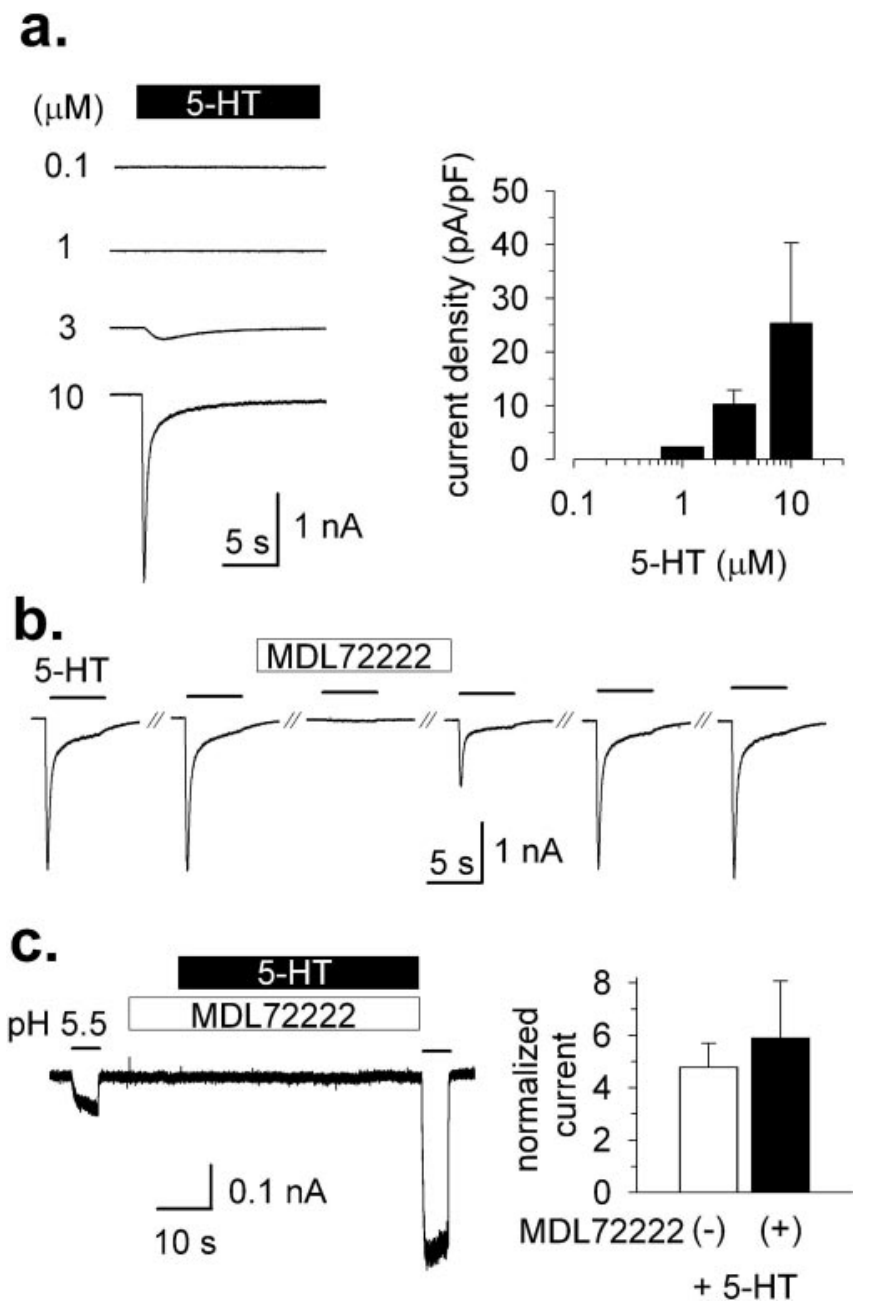

Figure 6. 5- $\mathrm{HT}_{3}$ channel is activated by $5-\mathrm{HT}$ in colon afferent neurons but does not contribute to serotonergic facilitation of TRPV1 function. $a$, Representative currents activated by increasing 5-HT concentrations $(0.1,1,3$, and $10 \mu \mathrm{m})$. The data were normalized to cell capacitance and are summarized in the right panel $(0.1 \mu \mathrm{m}, n=6 ; 1 \mu \mathrm{m}, n=9 ; 3 \mu \mathrm{m}, n=8 ; 10 \mu \mathrm{m}$, $n=8) . b$, The selective $5-\mathrm{HT}_{3}$ antagonist MDL-72222 (600 nM) reversibly blocked the inward current triggered by $10 \mu \mathrm{M} 5-\mathrm{HT}(n=6 ; t=25.3 ; p<0.001)$. $\mathrm{c}$, The $5-\mathrm{HT}_{3}$ antagonist MDL7222 did not block facilitation by 5 -HT $(1 \mu \mathrm{m})$ of the acid-evoked current. The data summarized to the right for vehicle (unfilled bar; $n=11$ ) and MDL72222 (filled bar; $n=8$; $t=-0.52$; not significant) treatments are shown.

sustained currents that were blocked by capazepine, but not by amiloride, and thus likely are attributable to activation of TRPV1. A previous study of unidentified DRG neurons reported a mixture of transient and sustained acid-sensitive currents, both of which were significantly inhibited by amiloride (Dirajlal et al., 2003), suggesting a significant contribution of ASICs. In addition, the majority of the mouse colon DRG neurons in the present study responded to heat, whereas in a previous study only about half of unidentified DRG neurons were heat sensitive (Nagy and Rang, 1999). Because the fraction of capsaicin-sensitive neurons innervating the rat colon is lower (Su et al., 1999), direct comparisons between identified somatic and visceral neurons in the same species are necessary to determine whether colon sensory neurons actually have properties distinct from other, somatic DRG neurons.

The present results point at a potential role of TRPV1 as a modulator of neuron excitability. Changes in TRPV1 function through phosphorylation or release from inhibition through

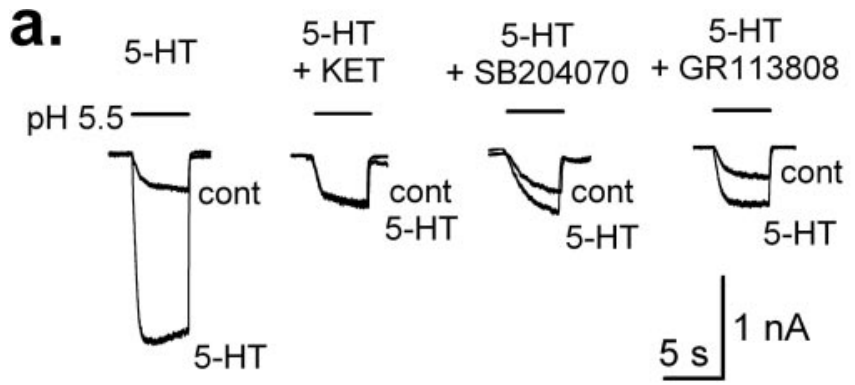

b. vehicle DOI $\alpha$ Me-5-HT cisapride 5-MeOT


Figure 7. Metabotropic 5-HT receptors are involved in serotonergic facilitation of TRPV1 activation in colon afferent neurons. $a$, Representative records of 5-HT-produced facilitation of acid-evoked currents before (cont) and after treatment with selective $5-\mathrm{HT}_{2}$ or $5-\mathrm{HT}_{4}$ receptor antagonists. Ketanserin (KET; $10 \mu \mathrm{m})$, SB204070 (10 $\mu \mathrm{M})$, or GR113808 (10 $\mu \mathrm{M})$ were added 5 sec before application of $5-\mathrm{HT}(1 \mu \mathrm{M}) . b$, Representative records of acid-elicited currents before (cont) and after treatment with vehicle or selective $5-\mathrm{HT}_{2}$ or $5-\mathrm{HT}_{4}$ receptor agonists. DOI (1 $\mu \mathrm{M}), \alpha$ Me-5-HT (1 $\mu \mathrm{M})$, cisapride (1 $\mu \mathrm{M})$, or 5-Me0T (1 $\mu \mathrm{M})$ were given for $50 \mathrm{sec}$ before the second acid stimulation. The data for antagonists $(c)$ and agonists $(d)$ are summarized as responses normalized to the amplitude of the initial proton-evoked current $\left[n=6-11\right.$; ${ }^{*} p<$ $0.05,{ }^{* *} p<0.01$, and ${ }^{* * *} p<0.001$ vs $5-\mathrm{HT}(c)$ or vehicle $(d) ; 1$-way ANOVA with Bonferroni $t$ test].

lipid mediators have previously been reported in response to bradykinin, ATP, nerve growth factor, and prostaglandin (Chuang et al., 2001; Tominaga et al., 2001; Bhave et al., 2003). Although these mediators play an important role in changes attributable to injury and inflammation, the effects of 5-HT on colon sensory neurons provides a mechanism by which physiological stimuli can trigger enhanced responses in normal tissue. Mucosal stimuli trigger 5-HT release from enteroendocrine cells, which in turn activates intrinsic and extrinsic primary afferent neurons within the gut wall (Pan and Gershon, 2000; Hicks et al., 2002). Given the apparent expression of TRPV1 in nearly all C57BL/6 colon DRG neurons, and the generation of spontaneous action potentials at normal body temperature after exposure to 5-HT, the activation of peripheral afferents may contribute to sensation and even conscious perception of visceral stimuli in the uninflamed gut.

Serotonin enhanced responses to TRPV1 activation at con- 

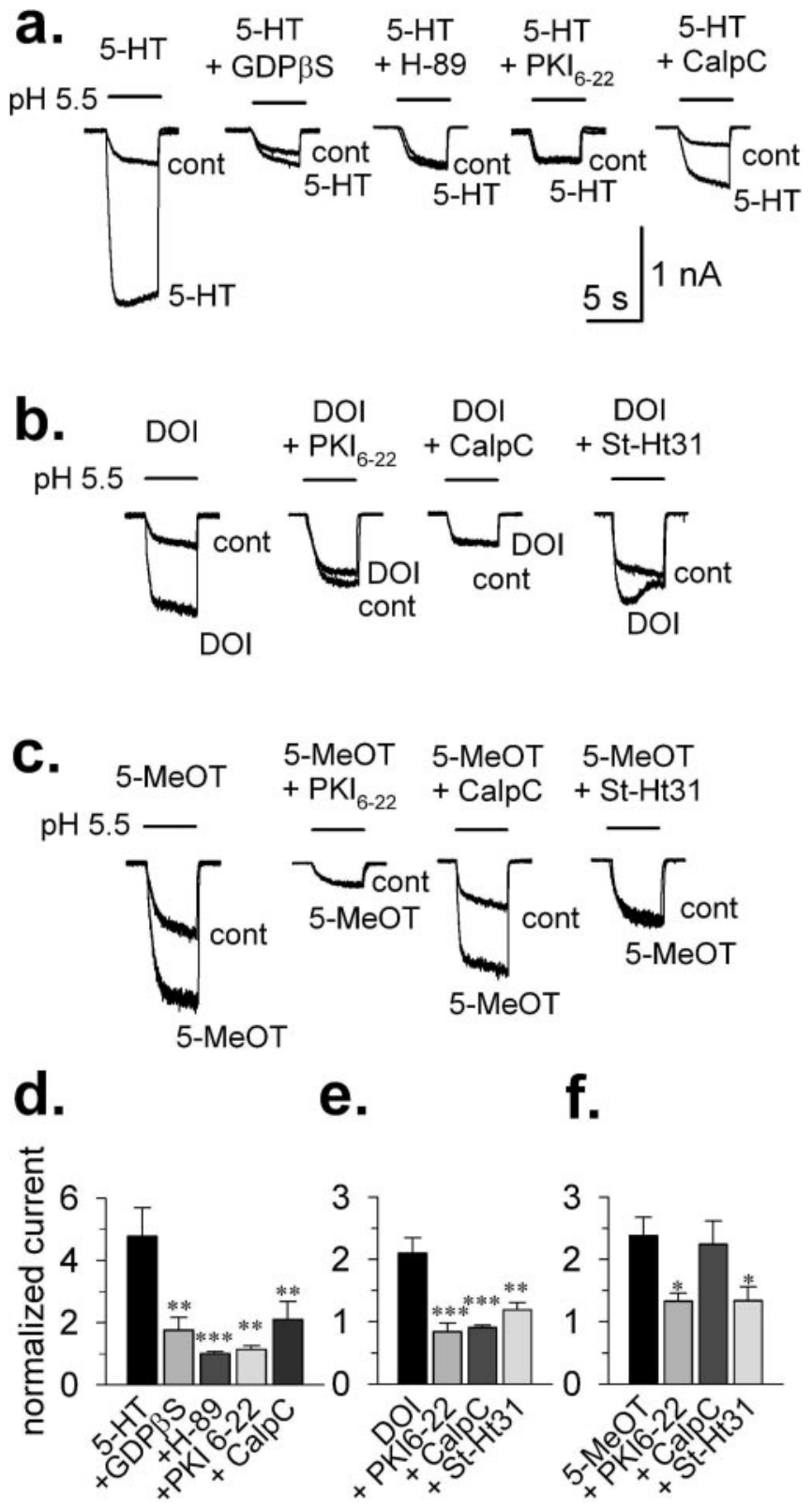

Figure 8. Intracellular signal transduction involved in serotonergic facilitation of TRPV1 activation in colon afferent neurons. $a$, Representative records of acid-elicited current before (cont) and after treatment with 5-HT in the absence or presence of inhibitors of intracellular signaling pathways. GDP- $\beta S(G D P \beta S ; 0.5 \mathrm{~mm}), \mathrm{H}-89(1 \mu \mathrm{M})$, protein kinase inhibitor $6-22$ amide $\left(\mathrm{PKI}_{6-22} ; 5 \mu \mathrm{M}\right)$, or calphostin $\mathrm{C}(\mathrm{CalpC} ; 1 \mu \mathrm{m})$ was added to the intracellular solution. $b$, $c$, Representative records of acid-evoked currents before (cont) and after treatment with DOI ( $b$ ) or 5-MeOT (c) in the absence or presence of intracellular pathway inhibitors. $\mathrm{PKI}_{6-22}(5 \mu \mathrm{m})$, CalpC $(1 \mu \mathrm{m})$, or AKAP inhibitor St-Ht31 $(5 \mu \mathrm{m})$ was added to the intracellular solution. The data are summarized for effects on 5-HT (d), DOI (e), and 5-Me0T ( $f)\left(n=6-11\right.$; ${ }^{*} p<0.05,{ }^{* *} p<$ 0.01 , and ${ }^{* * *} p<0.001 ; 1$-way ANOVA with Bonferroni $t$ test).

centrations below $1 \mu \mathrm{M}$ and without changes in baseline current, arguing against an involvement of the ligand-gated $5-\mathrm{HT}_{3}$ receptor. Consistent with these results, selective $5-\mathrm{HT}_{3}$ receptor antagonists did not inhibit enhancement of TRPV1 function by $5-\mathrm{HT}$, revealing that activation of metabotropic 5-HT receptors facilitates TRPV1 responses. To establish this experimentally, we blocked G-protein-coupled signaling pathways by adding GDP$\beta$-S to the pipette solution, which abolished TRPV1 modulation by $5-\mathrm{HT}$. We found that activation of both $5-\mathrm{HT}_{2}$ and $5-\mathrm{HT}_{4}$ receptors similarly enhanced TRPV1 function in colon sensory neurons. Whereas $5-\mathrm{HT}_{2}$ receptor agonists mimicked the facilitating action of 5-HT on TRPV1 function in response to acid, the $\mathrm{HT}_{4}$ receptor agonists cisapride and 5-MeOT had potencies lower than that of 5-HT, thus behaving only as partial agonists. The structures of these compounds and/or their receptor coupling efficiencies might explain the different potencies (Leung et al., 1996). In addition, these agonists may affect other 5-HT receptors (Hensley and Cohen, 1992; Sebben et al., 1994; Tsou et al., 1994). However, because the agonist-induced facilitation of TRPV1 function was significantly reversed by SB204070, a selective $5-\mathrm{HT}_{4}$ receptor antagonist, we consider their effects to represent actions at the $5-\mathrm{HT}_{4}$ receptor.

Phosphorylation of TRPV1 by PKA (Lopshire and Nicol, 1998; De Petrocellis et al., 2001) and/or PKC (Numazaki et al., 2002; Bhave et al., 2003) and/or regulation by PLC (Chuang et al., 2001) are mechanisms of sensitization of TRPV1 function. Metabotropic 5-HT receptors couple to $\mathrm{G}_{\mathrm{q} / 11}$ or $\mathrm{G}_{\mathrm{s}}$ proteins, and their downstream effectors PLC or adenyl cyclase (Raymund et al., 2001). 5- $\mathrm{HT}_{2}$ receptor activation can lead to activation of $\mathrm{G}_{\mathrm{q} / 11}$, resulting in activation of PLC and PKC (Conn and Sanders-Bush, 1984; Roth et al., 1986), and 5 $\mathrm{HT}_{4}$ receptor activation can lead to activation of $G_{s}$ and an increase in cAMP levels (Boess and Martin, 1994). Using selective protein kinase inhibitors, we found that $5-\mathrm{HT}_{2}$ receptor activation involved not only PKA but also PKC. Similarly, the effects of $5-\mathrm{HT}_{4}$ activation were attenuated by inhibitors of PKA and inhibitors of the interaction between PKA binding to the scaffold protein AKAP (Rathee et al., 2002). Surprisingly, 5-HT not only shifted the proton dosedependent curve to the left but also affected its slope. PKA (Mohapatra and Nau, 2003) has been reported to shift the capsaicin concentration-response relationship to the left in an approximately parallel manner. The reason for this discrepancy between two different ligands (capsaicin and proton) is unclear, but it might reflect the extracellular binding domain for protons in contrast to the intracellular binding site for capsaicin. Alternatively, the difference reflects use of a heterologous expression system and $\mathrm{Ca}^{2+}$-free solution as opposed to native DRG cells studied in the presence of $\mathrm{Ca}^{2+}$. The current observations suggest that enhancement of proton-evoked responses by 5 -HT change the proton-binding kinetics to TRPV1 in colon DRG neurons.

Several signaling pathways converge on TRPV1 to modulate its activity and, as shown in this and previous studies, alter neuron excitability (Bhave et al., 2003; Carr et al., 2003; Moriyama et al., 2003; Dai et al., 2004; Ferreira et al., 2004; Liu et al., 2004; Premkumar et al., 2004; Puntambekar et al., 2004). The potential role of TRPV1 in integrating different physical, chemical, and inflammatory signals and the comparatively high number of capsaicin-responsive colon sensory neurons support the relevance of this channel in sensation and visceral nociception. Consistent with these considerations, luminal application of capsaicin or capsaicin injection into the gut wall lowers sensory threshold or triggers pain in humans (Drewes et al., 2003; Schmulson et al., 2003; Lee et al., 2004). Interestingly, prolonged administration of red pepper, which contains capsaicin, improved symptoms in patients with functional dyspepsia (Bortolotti et al., 2002), likely because of neurotoxic effects of persistent TRPV1 stimulation that leads to transient analgesia in experimental models of neuropathic or inflammatory pain (Karai et al., 2004).

Previous studies demonstrated the presence of metabotropic 5 -HT receptors in intestinal afferent neurons and suggest that only a subgroup express $5-\mathrm{HT}_{3}$ receptors (Hillsley and Grundy, 
1998; Hicks et al., 2002). In addition to differential expression of 5-HT receptors, the onset and duration of 5-HT effects differed with stimulation of metabotropic receptors, causing a slower and longer-lasting stimulation. The modulation of TRPV1 function by 5 -HT reported here may increase afferent input from the colon and thus provide a peripheral mechanism for the development of symptoms in the absence of inflammation or injury. Although the present results suggest that activation of $5-\mathrm{HT}_{2}$ and $5-\mathrm{HT}_{4}$ receptors may affect visceral sensation, the multiplicity of 5-HT receptors and their expression in gastrointestinal smooth muscle cells and intrinsic neurons complicates the interpretation of 5-HT effects (Cooke et al., 1997; Jin et al., 1999; Michel et al., 1997; Borman et al., 2002). Spinal 5-HT receptors also play important roles in descending modulation of pain, including visceral pain (Urban and Gebhart, 1999), and drugs that cross the blood brain barrier may exert both peripheral and central effects. The peripherally acting $5-\mathrm{HT}_{3}$ receptor antagonist alosetron blunts responses to colorectal distension in experimental animals and improves discomfort and pain in a subgroup of patients with functional bowel disorders (Camilleri et al., 1999; Kozlowski et al., 2000). Interestingly, other $5-\mathrm{HT}_{3}$ receptor antagonists do not consistently affect visceral pain in experimental animals or humans (Langlois et al., 1996; Kim and Camilleri, 2000). Less is known about the effects of agonists and antagonists of metabotropic 5-HT receptors on visceral sensation. The recently introduced 5- $\mathrm{HT}_{4}$ receptor agonist tegaserod accelerates colonic transit but does not consistently affect sensory function in humans (Coffin et al., 2003; Lacy and Yu, 2002). Although a peripherally acting $5-\mathrm{HT}_{4}$ receptor antagonist has been reported to blunt somatic and visceral pain in mice, sensory thresholds to colorectal distension were not affected by inhibition of the $5-\mathrm{HT}_{4}$ receptor in humans (Espejo and Gil, 1998; Bharucha et al., 2000).

The present findings provide new information about a potential peripheral mechanism that contributes to visceral hypersensitivity. Additional studies in vitro and in vivo are needed to determine whether inhibition of TRPV1 channels or their modulation through 5-HT and/or other signaling pathways may be useful therapeutic targets in the treatment of visceral pain syndromes.

\section{References}

Barnes NM, Sharp T (1999) A review of central 5-HT receptors and their function. Neuropharmacology 38:1083-1152.

Bearcroft CP, Perrett D, Farthing MJ (1998) Postprandial plasma 5-hydroxytryptamine in diarrhoea predominant irritable bowel syndrome: a pilot study. Gut 42:42-46.

Bharucha AE, Camilleri M, Haydock S, Ferber I, Burton D, Cooper S, Tompson D, Fitzpatrick K, Higgins R, Zinsmeister AR (2000) Effects of a serotonin 5-HT(4) receptor antagonist SB-207266 on gastrointestinal motor and sensory function in humans. Gut 47:667-674.

Bhave G, Hu HJ, Glauner KS, Zhu W, Wang H, Brasier DJ, Oxford GS, Gereau RW (2003) Protein kinase C phosphorylation sensitizes but does not activate the capsaicin receptor transient receptor potential vanilloid 1 (TRPV1). Proc Natl Acad Sci USA 100:12480-12485.

Boess FG, Martin IL (1994) Molecular biology of 5-HT receptors. Neuropharmacology 33:275-317.

Borman RA, Tilford NS, Harmer DW, Day N, Ellis ES, Sheldrick RL, Carey J, Coleman RA, Baxter GS (2002) 5-HT(2B) receptors play a key role in mediating the excitatory effects of 5-HT in human colon in vitro. Br J Pharmacol 135:1144-1151.

Bortolotti M, Coccia G, Grossi G, Miglioli M (2002) The treatment of functional dyspepsia with red pepper. Aliment Pharmacol Ther 16:1075-1082.

Braha O, Edmonds B, Sacktor T, Kandel ER, Klein M (1993) The contributions of protein kinase $\mathrm{A}$ and protein kinase $\mathrm{C}$ to the actions of 5-HT on the L-type $\mathrm{Ca}^{2+}$ current of the sensory neurons in aplysia. J Neurosci 13:1839-1851.
Camilleri M, Mayer EA, Drossman DA, Heath A, Dukes GE, McSorley D, Kong S, Mangel AW, Northcutt AR (1999) Improvement in pain and bowel function in female irritable bowel patients with alosetron, a 5-HT3 receptor antagonist. Aliment Pharmacol Ther 13:1149-1159.

Camilleri M, Chey WY, Mayer EA, Northcutt AR, Heath A, Dukes GE, McSorley D, Mangel AM (2001) A randomized controlled clinical trial of the serotonin type 3 receptor antagonist alosetron in women with diarrhea-predominant irritable bowel syndrome. Arch Intern Med 161:1733-1740.

Cardenas CG, Del Mar LP, Cooper BY, Scroggs RS (1997a) 5HT4 receptors couple positively to tetrodotoxin-insensitive sodium channels in a subpopulation of capsaicin-sensitive rat sensory neurons. J Neurosci 17:7181-7189.

Cardenas CG, Del Mar LP, Scroggs RS (1997b) Two parallel signaling pathways couple 5HT1A receptors to $\mathrm{N}$ - and L-type calcium channels in C-like rat dorsal root ganglion cells. J Neurophysiol 77:3284-3296.

Cardenas LM, Cardenas CG, Scroggs RS (2001) 5HT increases excitability of nociceptor-like rat dorsal root ganglion neurons via cAMP-coupled TTX-resistant $\mathrm{Na}(+)$ channels. J Neurophysiol 86:241-248.

Carr MJ, Kollarik M, Meeker SN, Undem BJ (2003) A role for TRPV1 in bradykinin-induced excitation of vagal airway afferent nerve terminals. J Pharmacol Exp Ther 304:1275-1279.

Caterina MJ, Schumacher MA, Tominaga M, Rosen TA, Levine JD, Julius D (1997) The capsaicin receptor: a heat-activated ion channel in the pain pathway. Nature 389:816-824.

Caterina MJ, Leffler A, Malmberg AB, Martin WJ, Trafton J, Petersen-Zeitz KR, Koltzenburg M, Basbaum AI, Julius D (2000) Impaired nociception and pain sensation in mice lacking the capsaicin receptor. Science 288:306-313.

Chan CL, Facer P, Davis JB, Smith GD, Egerton J, Bountra C, Williams NS, Anand P (2003) Sensory fibres expressing capsaicin receptor TRPV1 in patients with rectal hypersensitivity and faecal urgency. Lancet 361:385-391.

Christian EP, Taylor GE, Weinreich D (1989) Serotonin increases excitability of rabbit C-fiber neurons by two distinct mechanisms. J Appl Physiol 67:584-591.

Chuang HH, Prescott ED, Kong H, Shields S, Jordt SE, Basbaum AI, Chao MV, Julius D (2001) Bradykinin and nerve growth factor release the capsaicin receptor from PtdIns(4,5)P2-mediated inhibition. Nature 411:957-962.

Coffin B, Farmachidi JP, Rueegg P, Bastie A, Bouhassira D (2003) Tegaserod, a 5-HT4 receptor partial agonist, decreases sensitivity to rectal distension in healthy subjects. Aliment Pharmacol Ther 17:577-585.

Conn PJ, Sanders-Bush E (1984) Selective 5HT-2 antagonists inhibit serotonin stimulated phosphatidylinositol metabolism in cerebral cortex. Neuropharmacology 23:993-996.

Cooke HJ, Sidhu M, Wang YZ (1997) 5-HT activates neural reflexes regulating secretion in the guinea-pig colon. Neurogastroenterol Motil 9:181-186.

Dai Y, Moriyama T, Higashi T, Togashi K, Kobayashi K, Yamanaka H, Tominaga M, Noguchi K (2004) Proteinase-activated receptor 2-mediated potentiation of transient receptor potential vanilloid subfamily 1 activity reveals a mechanism for proteinase-induced inflammatory pain. J Neurosci 24:4293-4299.

Davis JB, Gray J, Gunthorpe MJ, Hatcher JP, Davey PT, Overend P, Harries MH, Latcham J, Clapham C, Atkinson K, Hughes SA, Rance K, Grau E, Harper AJ, Pugh PL, Rogers DC, Bingham S, Randall A, Sheardown SA (2000) Vanilloid receptor-1 is essential for inflammatory thermal hyperalgesia. Nature 405:183-187.

De Petrocellis L, Harrison S, Bisogno T, Tognetto M, Brandi I, Smith GD, Creminon C, Davis JB, Geppetti P, Di Marzo V (2001) The vanilloid receptor (VR1)-mediated effects of anandamide are potently enhanced by the cAMP-dependent protein kinase. J Neurochem 77:1660-1663.

Dirajlal S, Pauers LE, Stucky CL (2003) Differential response properties of $\mathrm{IB}(4)$-positive and -negative unmyelinated sensory neurons to protons and capsaicin. J Neurophysiol 89:513-524.

Drewes AM, Schipper KP, Dimcevski G, Petersen P, Gregersen H, FunchJensen P, Arendt-Nielsen L (2003) Gut pain and hyperalgesia induced by capsaicin: a human experimental model. Pain 104:333-341.

Espejo EF, Gil E (1998) Antagonism of peripheral 5-HT4 receptors reduces visceral and cutaneous pain in mice, and induces visceral analgesia after simultaneous inactivation of 5-HT3 receptors. Brain Res 788:20-24. 
Ferreira J, da Silva GL, Calixto JB (2004) Contribution of vanilloid receptors to the overt nociception induced by $\mathrm{B} 2$ kinin receptor activation in mice. Br J Pharmacol 141:787-794.

Gershon MD (1999) Rev article: roles played by 5-hydroxytryptamine in the physiology of the bowel. Aliment Pharmacol Ther 13 [Suppl 2]:15-30.

Grundy D, Hillsley K, Kirkup AJ, Richards W (1998) Mesenteric afferent sensitivity to cholecystokinin and 5-hydroxytryptamine. Dtsch Tierarztl Wochenschr 105:466-468.

Hensley SH, Cohen JL (1992) Effects of serotonergic agonists and antagonists on ganglion cells in the goldfish retina. Vis Neurosci 9:353-364.

Hicks GA, Coldwell JR, Schindler M, Ward PA, Jenkins D, Lynn PA, Humphrey PP, Blackshaw LA (2002) Excitation of rat colonic afferent fibres by 5-HT(3) receptors. J Physiol (Lond) 544:861-869.

Hillsley K, Grundy D (1998) Sensitivity to 5-hydroxytryptamine in different afferent subpopulations within mesenteric nerves supplying the rat jejunum. J Physiol (Lond) 15:717-727.

Houghton LA, Atkinson W, Whitaker RP, Whorwell PJ, Rimmer MJ (2003) Increased platelet depleted plasma 5-hydroxytryptamine concentration following meal ingestion in symptomatic female subjects with diarrhoea predominant irritable bowel syndrome. Gut 52:663-670.

Jin JG, Foxx-Orenstein AE, Grider JR (1999) Propulsion in guinea pig colon induced by 5-hydroxytryptamine (HT) via 5-HT4 and 5-HT3 receptors. J Pharmacol Exp Ther 288:93-97.

Karai L, Brown DC, Mannes AJ, Connelly ST, Brown J, Gandal M, Wellisch OM, Neubert JK, Olah Z, Iadarola MJ (2004) Deletion of vanilloid receptor 1-expressing primary afferent neurons for pain control. J Clin Invest 113:1344-1352.

Kim DY, Camilleri M (2000) Serotonin: a mediator of the brain-gut connection. Am J Gastroenterol 95:2698-2709.

Kozlowski CM, Green A, Grundy D, Boissonade FM, Bountra C (2000) The 5-HT(3) receptor antagonist alosetron inhibits the colorectal distention induced depressor response and spinal c-fos expression in the anaesthetised rat. Gut 46:474-480.

Lacy BE, Yu S (2002) Tegaserod: a new 5-HT4 agonist. J Clin Gastroenterol 34:27-33.

Langlois A, Pascaud X, Junien JL, Dahl SG, Riviere PJ (1996) Response heterogeneity of 5-HT3 receptor antagonists in a rat visceral hypersensitivity model. Eur J Pharmacol 318:141-144.

Lee KJ, Vos R, Tack J (2004) Effects of capsaicin on the sensorimotor function of the proximal stomach in humans. Aliment Pharmacol Ther 19:415-425.

Leung E, Pulido-Rios MT, Bonhaus DW, Pekins LA, Zeitung KD, Hsu SA, Clark RD, Wong EH, Eglen RM (1996) Comparison of 5-HT4 receptors in guinea-pig colon and rat oesophagus: effects of novel agonists and antagonists. Naunyn Schmiedebergs Arch Pharmacol 354:145-156.

Liu L, Zhu W, Zhang ZS, Yang T, Grant A, Oxford G, Simon SA (2004) Nicotine inhibits voltage-dependent sodium channels and sensitizes vanilloid receptors. J Neurophysiol 91:1482-1491.

Lopshire JC, Nicol GD (1998) The cAMP transduction cascade mediates the prostaglandin E2 enhancement of the capsaicin-elicited current in rat sensory neurons: whole-cell and single-channel studies. J Neurosci 18:6081-6092.

Mazzia C, Hicks GA, Clerc N (2003) Neuronal location of 5-hydroxytryptamine3 receptor-like immunoreactivity in the rat colon. Neuroscience 116:1033-1041.

Michael GJ, Priestley JV (1999) Differential expression of the mRNA for the vanilloid receptor subtype 1 in cells of the adult rat dorsal root and nodose ganglia and its downregulation by axotomy. J Neurosci 19:1844-1854.

Michel K, Sann H, Schaaf C, Schemann M (1997) Subpopulations of gastric myenteric neurons are differentially activated via distinct serotonin receptors: projection, neurochemical coding, and functional implications. J Neurosci 17:8009-8017.

Mohapatra DP, Nau C (2003) Desensitization of capsaicin-activated currents in the vanilloid receptor TRPV1 is decreased by the cyclic AMPdependent protein kinase pathway. J Biol Chem 278:50080-50090.

Moriyama T, Iida T, Kobayashi K, Higashi T, Fukuoka T, Tsumura H, Leon C, Suzuki N, Inoue K, Gachet C, Noguchi K, Tominaga M (2003) Possible involvement of P2Y2 metabotropic receptors in ATP-induced transient receptor potential vanilloid receptor 1-mediated thermal hypersensitivity. J Neurosci 23:6058-6062.
Nagy I, Rang H (1999) Noxious heat activates all capsaicin-sensitive and also a sub-population of capsaicin-insensitive dorsal root ganglion neurons. Neuroscience 88:995-997.

Nicholson R, Small J, Dixon AK, Spanswick D, Lee K (2003) Serotonin receptor mRNA expression in rat dorsal root ganglion neurons. Neurosci Lett 337:119-122.

Numazaki M, Tominaga T, Toyooka H, Tominaga M (2002) Direct phosphorylation of capsaicin receptor VR1 by protein kinase Cepsilon and identification of two target serine residues. J Biol Chem 277:13375-13378.

Pan H, Gershon MD (2000) Activation of intrinsic afferent pathways in submucosal ganglia of the guinea pig small intestine. J Neurosci 20:3295-3309.

Patapoutian A, Peier AM, Story GM, Viswanath V (2003) ThermoTRP channels and beyond: mechanisms of temperature sensation. Nat Rev Neurosci 4:529-539.

Premkumar LS, QiZH, Van Buren J, Raisinghani M (2004) Enhancement of potency and efficacy of NADA by PKC-mediated phosphorylation of vanilloid receptor. J Neurophysiol 91:1442-1449.

Puntambekar P, Van Buren J, Raisinghani M, Premkumar LS, Ramkumar V (2004) Direct interaction of adenosine with the TRPV1 channel protein. J Neurosci 24:3663-3671.

Rathee PK, Distler C, Obreja O, Neuhuber W, Wang GK, Wang SY, Nau C, Kress M (2002) PKA/AKAP/VR-1 module: a common link of Gsmediated signaling to thermal hyperalgesia. J Neurosci 22:4740-4745.

Raymond JR, Mukhin YV, Gelasco A, Turner J, Collinsworth G, Gettys TW, Grewal JS, Garnovskaya MN (2001) Multiplicity of mechanisms of serotonin receptor signal transduction. Pharmacol Ther 92:179-212.

Robinson DR, McNaughton PA, Evans ML, Hicks GA (2004) Characterization of the primary spinal afferent innervation of the mouse colon using retrograde labelling. Neurogastroenterol Motil 16:113-124.

Roth BL, Nakaki T, Chuang DM, Costa E (1986) 5-Hydroxytryptamine2 receptors coupled to phospholipase $\mathrm{C}$ in rat aorta: modulation of phosphoinositide turnover by phorbol ester. J Pharmacol Exp Ther 238:480-485.

Sandler RS, Everhart JE, Donowitz M, Adams E, Cronin K, Goodman C, Gemmen E, Shah S, Avdic A, Rubin R (2002) The burden of selected digestive diseases in the United States. Gastroenterology 122:1500-1511.

Schmulson MJ, Valdovinos MA, Milke P (2003) Chili pepper and rectal hyperalgesia in irritable bowel syndrome. Am J Gastroenterol 98:1214-1215.

Sebben M, Ansanay H, Bockaert J, Dumuis A (1994) 5-HT6 receptors positively coupled to adenylyl cyclase in striatal neurones in culture. NeuroReport 5:2553-2557.

Spiller RC, Jenkins D, Thornley JP, Hebden JM, Wright T, Skinner M, Neal KR (2000) Increased rectal mucosal enteroendocrine cells, T lymphocytes, and increased gut permeability following acute Campylobacter enteritis and in post-dysenteric irritable bowel syndrome. Gut 47:804-811.

Su X, Wachtel RE, Gebhart GF (1999) Capsaicin sensitivity and voltagegated sodium currents in colon sensory neurons from rat dorsal root ganglia. Am J Physiol 277:G1180-G1188.

Sugiura T, Tominaga M, Katsuya H, Mizumura K (2002) Bradykinin lowers the threshold temperature for heat activation of vanilloid receptor 1 . J Neurophysiol 88:544-548.

Tominaga M, Wada M, Masu M (2001) Potentiation of capsaicin receptor activity by metabotropic ATP receptors as a possible mechanism for ATPevoked pain and hyperalgesia. Proc Natl Acad Sci USA 98:6951-6956.

Torres GE, Chaput Y, Andrade R (1995) Cyclic AMP and protein kinase A mediate 5-hydroxytryptamine type 4 receptor regulation of calciumactivated potassium current in adult hippocampal neurons. Mol Pharmacol 47:191-197.

Tsou AP, Kosaka A, Bach C, Zuppan P, Yee C, Tom L, Alvarez R, Ramsey S, Bonhaus DW, Stefanich E (1994) Cloning and expression of a 5-hydroxytryptamine7 receptor positively coupled to adenylyl cyclase. J Neurochem 63:456-464.

Urban MO, Gebhart GF (1999) Central mechanisms in pain. Med Clin North Am 83:585-596.

Yiangou Y, Facer P, Dyer NH, Chan CL, Knowles C, Williams NS, Anand P (2001) Vanilloid receptor 1 immunoreactivity in inflamed human bowel. Lancet 357:1338-1339. 